\title{
STATUS IDENTIFICATION AND PREDICTION OF KAZIRANGA-KARBI ANGLONG WILDLIFE CORRIDOR OF ASSAM, INDIA, USING GEOSPATIAL TECHNOLOGY
}

\author{
BHAVNA SHARMA ${ }^{1}$, KIRANMAY SARMA $^{1 *}$ \\ ${ }^{1}$ University School of Environment Management, Guru Gobind Singh Indraprastha \\ University, Sector 16C, Dwarka, New Delhi 110078, *email: kiranmayipu@gmail.com/ \\ kiranmay@ipu.ac.in
}

Received: $26^{\text {th }}$ February 2014, Accepted: $16^{\text {th }}$ September 2014

\begin{abstract}
In the present study, an attempt has been made to discover the impacts of various developmental activities on the Kaziranga-Karbi Anglong wildlife corridor of Assam, India, using geospatial technology; as well as to predict the future status of the wildlife corridor by using the Cellular Automata Markov Model. Due to various anthropogenic activities the condition of the natural corridor has deteriorated, and in recent years many wild animals have been killed by road traffic accidents; in particular, greater one-horned (Indian) rhinoceros (Rhinoceros unicornis) are killed indiscriminately by the poachers, having been deviated from their regular routes. Changes were evident during the two decades between 1990 and 2010, when a large number of dense forest areas were converted to open forest, combined with losses of areas of scrub and marshy land. The area under agriculture and plantation crop increased along with the grassland during the decades. It has been found that the forests in Kaziranga-Karbi Anglong corridor are fragmented, and the area within the corridor is shrinking. There is considerable increase in patchiness, proportion of edge, and a perforated reduction of core areas within the corridor. The predicted land use/cover map of Kaziranga-Karbi Anglong corridor shows expansion of agricultural land, as well as plantation areas. It is estimated that only 25.66 percent of the present dense forest and 20.72 percent of open forest will remain by 2030, while areas under agriculture and plantation will increase by 33.91 and 5.33 percent, respectively.
\end{abstract}

Key words: Wildlife corridor, Kaziranga-Karbi Anglong, Forest fragmentation, Geospatial technology

\section{INTRODUCTION}

Habitat loss, fragmentation and isolation have been cited as critical threats, and the most common causes of the loss of present-day faunal and floral species (Conner \& Rudolph, 1991). Corridors link core biological areas, facilitate animal movement, preserve wildlife against land fragmentation, and are considered to be important geographic features for biological conservation and biodiversity assessment (Vogt et al., 2007). These wildlife corridors are believed to hold more promise for the conservation of biodiversity than any other management factors (Goetz et al., 2009). The pressure of modernisation and 
Sharma, B., Sarma, K.: Status Identification and Prediction of Kaziranga-Karbi Anglong Wildlife Corridor of Assam, India, Using Geospatial Technology

globalisation, along with unprecedented growth of human population and resultant commercial exploitation, have been prime causes of habitat fragmentation, range reduction, and shrinking corridors between the protected areas (Joshi et al., 2011) as well as declining wildlife in many developing countries, including India (Kushwaha et al., 2004; Hess et al., 2001; Alfred et al., 2001). Quantification and analysis of current impacts on wildlife habitat are vital for wildlife management, which involves the management of the complete ecosystem (Kushwaha et al., 2000). The greatest challenge to preserving wildlife is maintaining biological integrity of the surrounding habitat mosaic, and connectivity between protected areas. There is an urgent need to establish corridors between the remnant core areas, to maintain vital ecological connections by providing physical linkage between these areas (Mondal et al., 2010). Geospatial technology has been widely used to monitor ecological impacts, changes within corridors, and to provide the capabilities to study and interpret wildlife habitat information on different timescales (Yadav et al., 2012; Areendran et al., 2011; Nandy et al., 2007; Ravan et al., 2005).

The Kaziranga-Karbi Anglong landscape of Assam is a vitally important World Heritage Site, situated within the Indo-Burma biodiversity hotspot. Once sparsely populated and undisturbed, Karbi Anglong forests and grasslands of Kaziranga National Park formed one contiguous unit of ideal wildlife habitat. However, with the gradual opening up of the area, forest cover has been ruthlessly cut down, therefore damaging the habitat of wild animal species. Expansion of tea gardens is occurring at an alarming rate within the corridor, and heavy vehicular traffic (along the NH 37) bisects the corridor in the southern fringe of the national park; both are serious concerns for wildlife managers (Kushwaha et al., 2000). In recent times the destruction of the natural corridor has caused the greater one-horned rhinoceros to deviate from its historic routes; this has resulted in increased mortality through indiscriminate hunting by poachers. In the present study an attempt has been made to determine the impacts of various developmental activities on the Kaziranga-Karbi Anglong wildlife corridor of the northeastern state of Assam, India, using geospatial technology, and to predict the future status of the wildlife corridor by using CA Markov Model.

\section{LITERATURE REVIEW}

The study of various aspects of wildlife corridors using geospatial technology is of global interest (Vogt et al., 2007; Michelle et al., 2008; Zeller et al., 2011; Saura et al., 2009; Goetz et al., 2009). In India Ravan et al. (2005) and Roy et al. (2010) have conducted spatial analysis for identification and estimation of forested corridors in central India, where many of those are on the verge of destruction. Nandy et al. (2007) analysed the Chilla-Motichur wildlife corridor in Uttrakahand using remote sensing data, and emphasised the conservation problems in the corridor area. Joshi et al. (2011) identified migratory corridors between Rajaji and Jim Corbett National Parks, the two most important protected areas in the Himalayan foothills, using temporal remote sensing data. In their study, Multi-Layer Perceptron Neural Network (MLPNN) model was used for future prediction of land use/cover within the corridor. Menon et al. (2005) identified important wildlife corridors used by elephants in India, and analysed the major threats which are affecting these corridors. Rathore et al. (2012) identified a suitable wildlife corridor between Kanha and Pench National Parks of Central India using GIS-Centric Least Cost Path modelling, to identify likely routes for movements of tigers. Yadav et al. (2012) researched the Nagzira-Navegaon corridor of central India while studying land use/cover change and human wildlife conflict. Forest cover prediction in northeastern India was studied by Kushwaha (2008) along the 
foothills of the Himalayas, using temporal satellite imagery and Cellular Automata Markov Model (CAMM). Sarma et al. (2009) studied the status and causes of migration of greater one-horned rhinoceros, due to corridor destruction, in the Pabitora wildlife sanctuary of Assam, using multi-temporal satellite data. Land use/cover changes along the corridors of Golaghat district of Assam, using multi temporal remote sensing data, was undertaken by Phukan et al. (2013). The findings of Barua et al. (2010) revealed the causes of human elephant conflicts within the corridor between Kaziranga National Park and Karbi Anglong in Assam, and quantified the losses in the villages located in and around the wildlife corridor.

\section{MATERIAL AND METHODS}

\section{Study area}

Kaziranga National Park (KNP), a World heritage site, is famous for the greater one-horned (Indian) rhinoceros where it supports two-thirds of its global population. The geographical extension of the KNP is $92^{\circ} 50^{\prime}$ and $93^{\circ} 41^{\prime} \mathrm{E}$ longitude, and $26^{\circ} 30^{\prime}$ and $26^{\circ} 50^{\prime} \mathrm{N}$ latitude, covering the districts of Golaghat and Nagaon (Fig. 1).

\section{Fig. 1: Location of Kaziranga National Park in Assam}

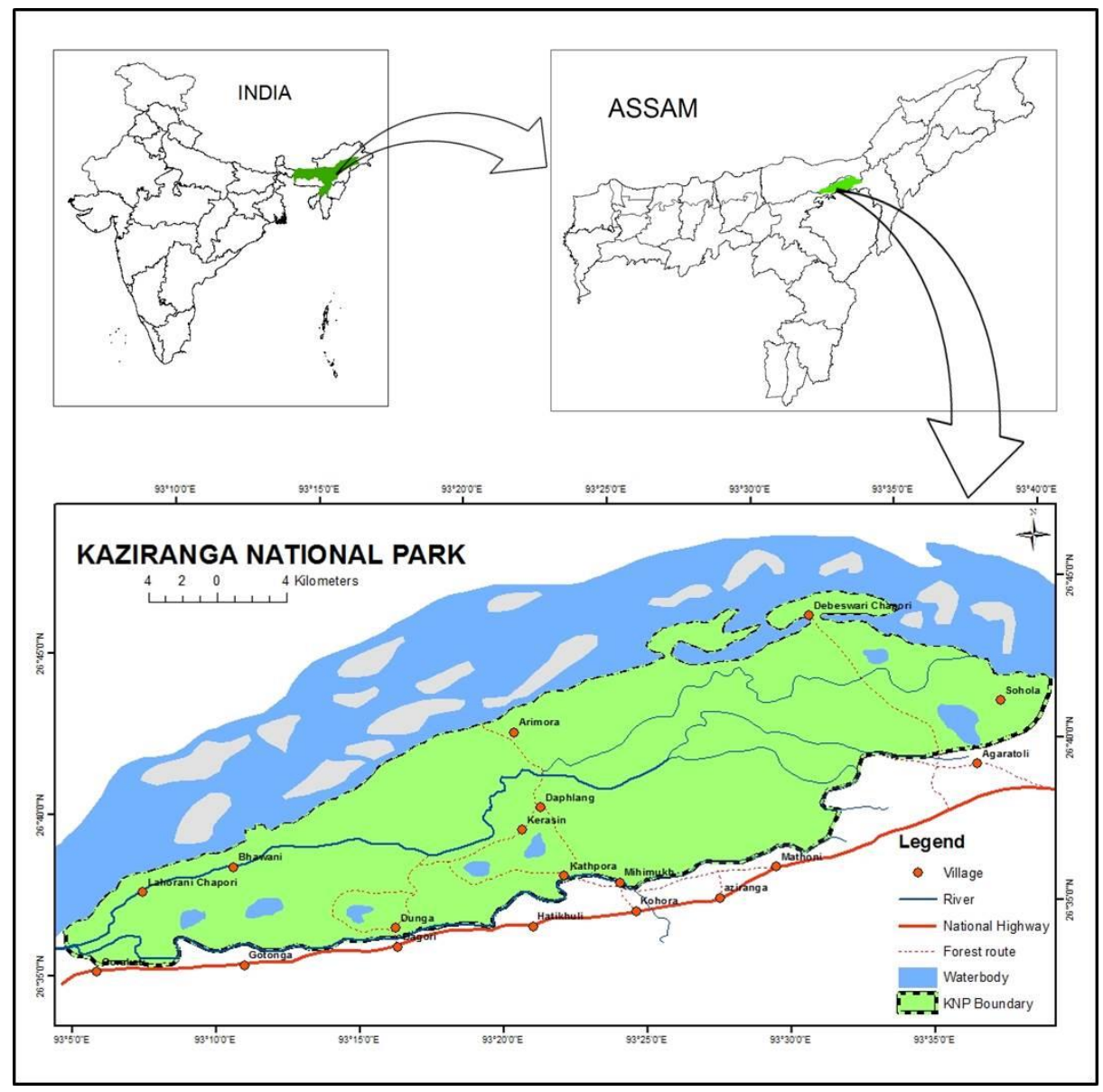


Sharma, B., Sarma, K.: Status Identification and Prediction of Kaziranga-Karbi Anglong Wildlife Corridor of Assam, India, Using Geospatial Technology

The vegetation of the KNP consists of extensive alluvial grasslands, with tall and short grasses interspersed by semi-evergreen forests. The grasslands have been classified as Eastern Wet Alluvial Grasslands by Champion and Seth (1968). The forest is dominated by trees such as Aphanamixis polystachya, Talauma hodgsonii, Dillenia indica, Garcinia tinctoria, Ficus sp., Cinnamomum bejolghota and Syzygium sp. The KNP is also endowed with a diverse fauna, containing approximately 15 mammal, 490 bird and 25 reptile species. Besides the rhinoceros, other mammal species found in abundance in Kaziranga are elephant, tiger, wild buffalo, wild boar, hog deer, sambar, hoolock gibbon, capped langur and rhesus macaque, sloth bear, otter, Gangetic dolphin, barking deer and Malayan giant squirrel (Khuswaha et al., 2008). For the present study an area of 11,799.24 sq.km, between the KNP and Karbi Anglong, has been identified to research the past and present status of the corridor, and to predict the future scenario.

\section{Materials and Methods}

For the Kaziranga-Karbi Anglong wildlife corridor study, temporal remote sensing imagery taken in 1990 and 2010 were utilised (Table 1). The satellite images with bands (7) were stacked to prepare an FCC of bands 4(Red), 3(Green) and 2(Blue). The relevant topographic maps and images were geometrically recreated to $1: 50,000$ scale, using geographic projection system UTM; the speroid and datum used were WGS 84. The study area falls in the UTM zone of 46N. The GIS and image processing software used was ArcGIS 10.1, Erdas Imagine 2014 and IDRISI Selva 17.00. The paradigm for the study is described in Fig. 2 and Fig. 3. Field verification was carried out during $1^{\text {st }}$ February to $11^{\text {th }}$ April 2013.

Table 1: Details of the satellite imagery used for the study

\begin{tabular}{|c|c|c|}
\hline Satellite and Sensor & Path/Row & Date of Acquisition \\
\hline Landsat TM & $135 / 41,42$ & $09-11-1990$ \\
\hline Landsat TM & $136 / 41,42$ & $25-12-1990$ \\
\hline Landsat TM & $135 / 41,42$ & $08-02-2010$ \\
\hline Landsat TM & $136 / 41,42$ & $21-03-2010$ \\
\hline
\end{tabular}




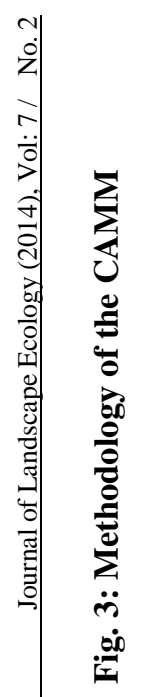
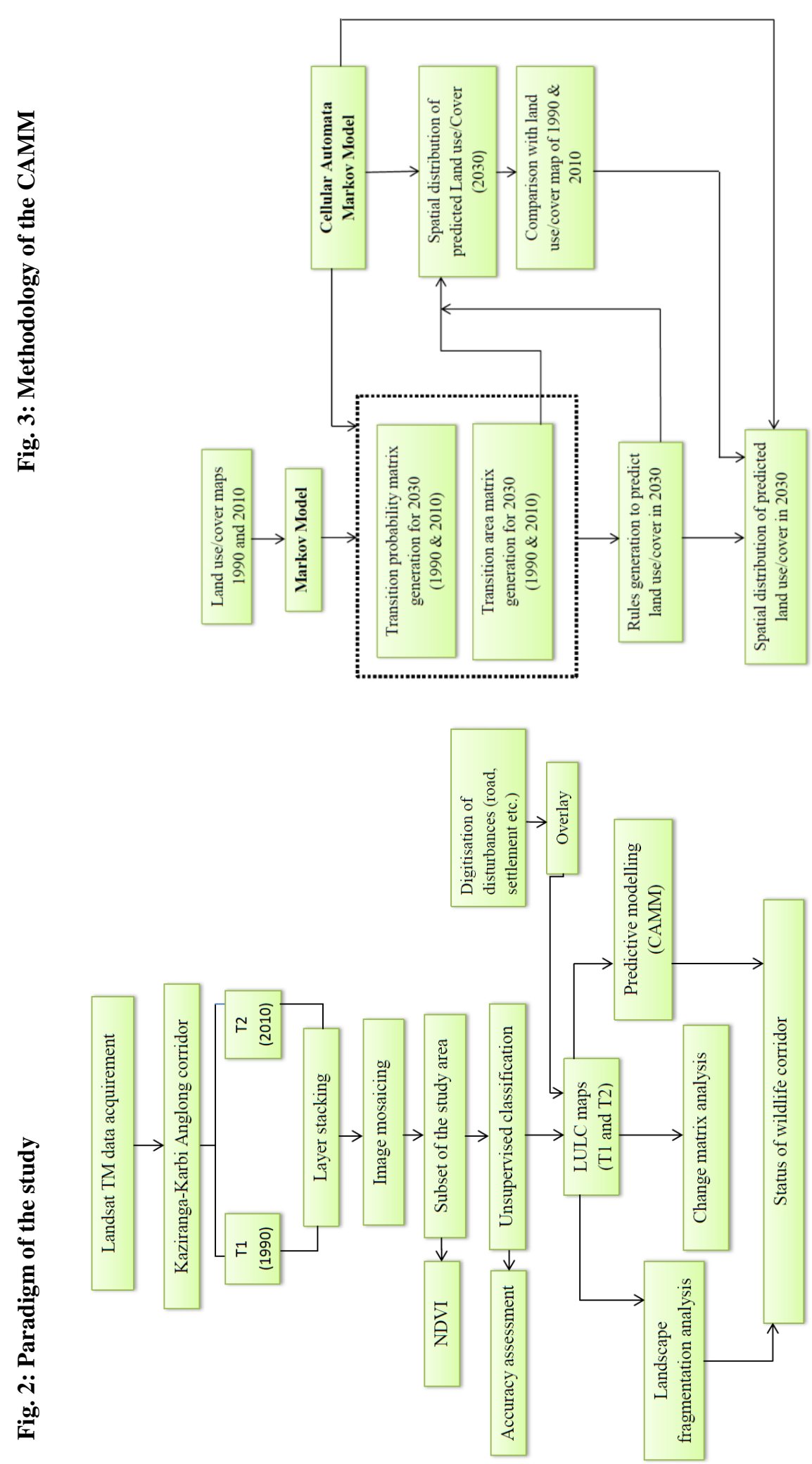
Sharma, B., Sarma, K.: Status Identification and Prediction of Kaziranga-Karbi Anglong Wildlife Corridor of Assam, India, Using Geospatial Technology

\section{RESULTS}

\section{Land use/cover}

The land use/cover maps prepared for years 1990 and 2010 were classified into 9 classes, namely; river, marshy area, dense forest, open forest, scrub forest, agriculture, open area/river bed, grassland and plantation for Kaziranga-Karbi Anglong corridor (Fig. 4). It is evident from the study that there were remarkable conversions within the corridor, from dense to open forests during the last two decades (Table 2). There were also losses of scrub forest and marshy land during the study period, while the area categorised as grassland increased. The proportion of agricultural land within the corridor has increased considerably during the last two decades. Details about the change in habitat matrix are given in Table 3. The main disturbances for the movement of wildlife in the area are heavy vehicular movements along the National Highway 37, tea plantation and allied activities and corridor dependent villages, mainly human habitation and agricultural activity (Fig. 5). The accuracy was estimated by calculating a set of Kappa statistics proposed by Pontius (2000), based on ground truth points selected at random (Table 4).

Fig. 4: Land use/ cover of Kaziranga-Karbi Anglong Corridor in 1990 and 2010

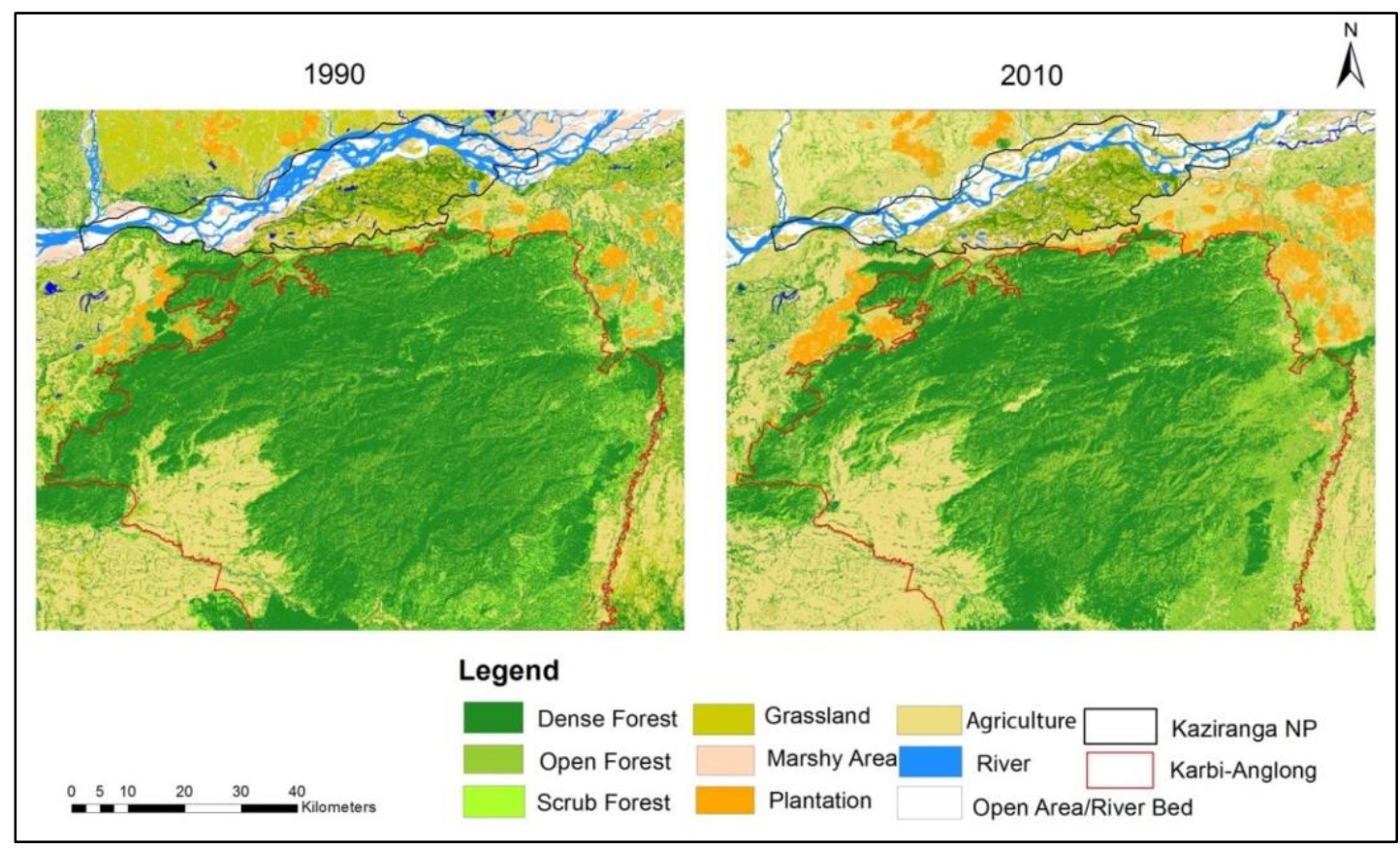


Table 2: Area statistics of Kaziranga-Karbi Anglong corridor during 1990 and 2010

\begin{tabular}{|c|c|c|c|c|}
\hline & \multicolumn{2}{|c|}{ Area in sq.km (\%) } & Area in sq.km & \\
\hline Land use/cover class & Year 1990 & Year 2010 & Net Change & Gain/Loss \\
\hline River & $444.70(3.77)$ & $243.76(2.07)$ & -200.94 & Loss \\
\hline Marshy Area & $312.49(2.65)$ & $266.60(2.26)$ & -45.89 & Loss \\
\hline Dense forest & $4,777.68(40.49)$ & $3,609.38(30.59)$ & $-1,168.30$ & Loss \\
\hline Open forest & $1,319.81(11.19)$ & $2,404.57(20.38)$ & $1,084.77$ & Gain \\
\hline Scrub forest & $712.48(6.04)$ & $411.75(3.49)$ & -300.73 & Loss \\
\hline Agriculture & $3,303.25(28.00)$ & $3,557.10(30.15)$ & 253.85 & Gain \\
\hline Open Area/river bed & $325.64(2.76)$ & $382.79(3.24)$ & 57.15 & Gain \\
\hline Grassland & $355.72(3.01)$ & $452.54(3.84)$ & 96.82 & Gain \\
\hline Plantation & $247.47(2.10)$ & $470.74(3.99)$ & 223.27 & Gain \\
\hline Total Area & $\mathbf{1 1 , 7 9 9 . 2 4 ( 1 0 0 )}$ & $\mathbf{1 1 , 7 9 9 . 2 4 ( 1 0 0 )}$ & - & - \\
\hline
\end{tabular}

Table 3: Change matrix for Kaziranga-Karbi Anglong corridor in 1990 and 2010

\begin{tabular}{|c|c|c|c|c|c|c|c|c|c|c|c|}
\hline Year & \multicolumn{11}{|c|}{2010} \\
\hline \multirow{11}{*}{1990} & & $\mathbf{R}$ & MA & DF & OF & SF & Agr & OA & GL & PLN & TA \\
\hline & $\mathrm{R}$ & 89.64 & 108.25 & 0 & 0 & 0 & 57.33 & 189.47 & 0 & 0 & 444.70 \\
\hline & MA & 75.65 & 64.56 & 0 & 0 & 0 & 97.35 & 78.41 & 0 & 0 & 312.49 \\
\hline & $\mathrm{DF}$ & 0 & 0 & 2887.57 & 1152.41 & 213.49 & 451.11 & 9.66 & 4.68 & 64.42 & 4777.68 \\
\hline & OF & 0 & 0 & 458.01 & 725.07 & 37.01 & 104.38 & 3.28 & 0.00 & 58.02 & 1319.81 \\
\hline & SF & 0 & 0 & 254.99 & 229.06 & 72.22 & 136.45 & 0.64 & 1.23 & 25.65 & 712.48 \\
\hline & Agr & 19.32 & 0 & 0 & 0 & 0 & 2998.27 & 101.08 & 0 & 210.78 & 3307.18 \\
\hline & $\mathrm{OA}$ & 61.17 & 77.89 & 0 & 0 & 0.43 & 24.26 & 112.75 & 0 & 53.57 & 325.64 \\
\hline & GL & 0 & 0 & 0 & 0 & 0.81 & 9.51 & 11.00 & 332.75 & 0.22 & 355.72 \\
\hline & PLN & 0 & 0 & 2.88 & 0 & 1.13 & 62.53 & 0.15 & 0.49 & 175.97 & 243.55 \\
\hline & TA & 243.76 & 266.60 & 3609.38 & 2404.57 & 411.75 & 3576.72 & 382.79 & 452.54 & 451.12 & 11799.24 \\
\hline
\end{tabular}

Units: Sq.km

$\mathrm{R}=$ River, $\mathrm{MA}=$ Marshy Area, $\mathrm{DF}=$ Dense forest, $\mathrm{OF}=$ Open forest, $\mathrm{SF}=\mathrm{Scrub}$ forest, Agr=Agriculture, $\mathrm{OA}=\mathrm{Open}$

Area/river bed, GL=Grassland, PLN=Plantation, TA=Total Area

Table 4: Accuracy assessment of the classifications

\begin{tabular}{|c|c|c|}
\hline Year & Overall accuracy & Overall Kappa coefficient \\
\hline 1990 & $82.67 \%$ & 0.7332 \\
\hline 2010 & $84.00 \%$ & 0.7868 \\
\hline
\end{tabular}


Sharma, B., Sarma, K.: Status Identification and Prediction of Kaziranga-Karbi Anglong Wildlife Corridor of Assam, India, Using Geospatial Technology

\section{Fig. 5: Disturbances in Kaziranga-Karbi Anglong corridor during 2010}

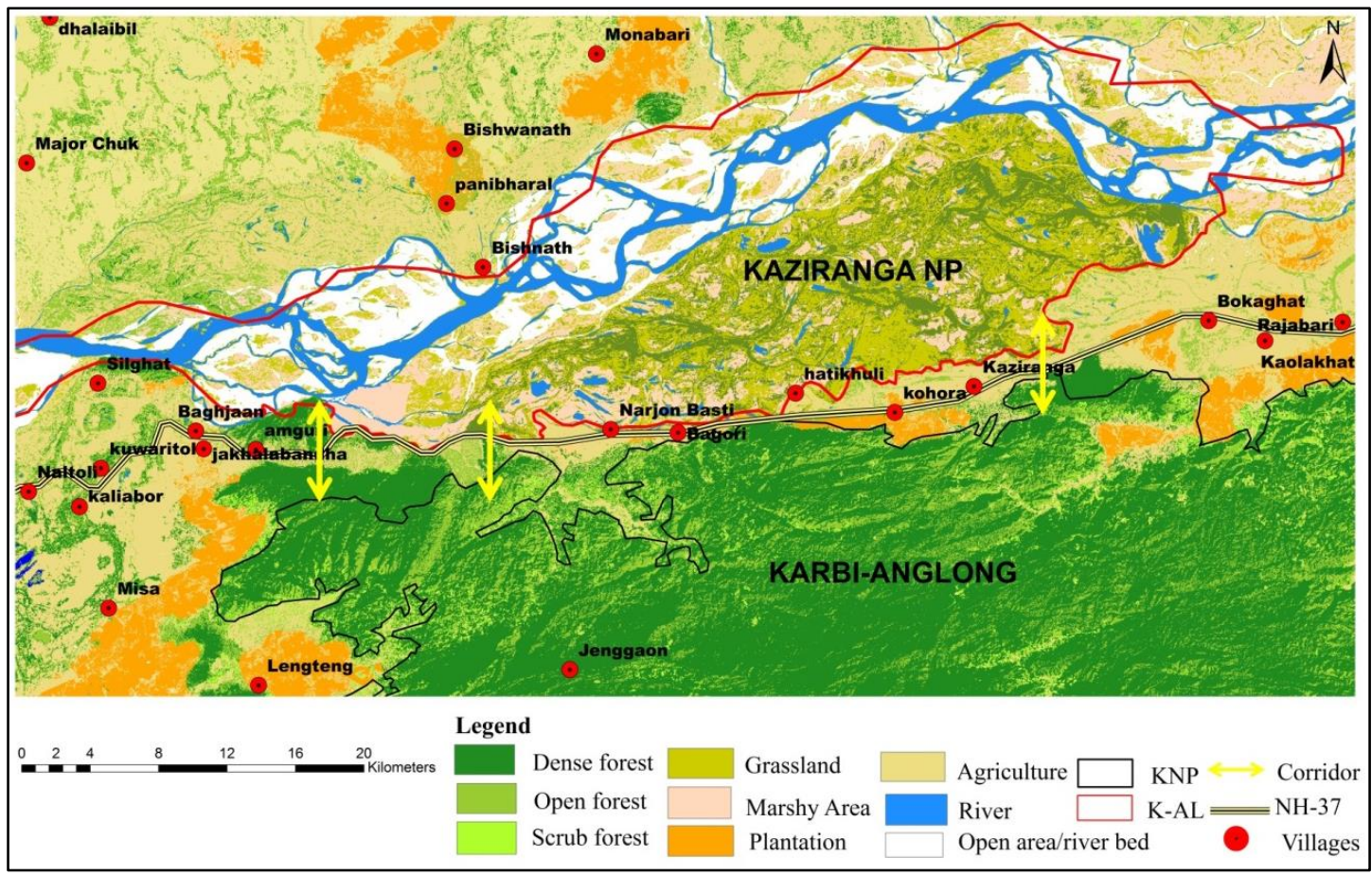

Fig. 6: NDVI of Kaziranga-Karbi Anglong corridor in 1990 and 2010

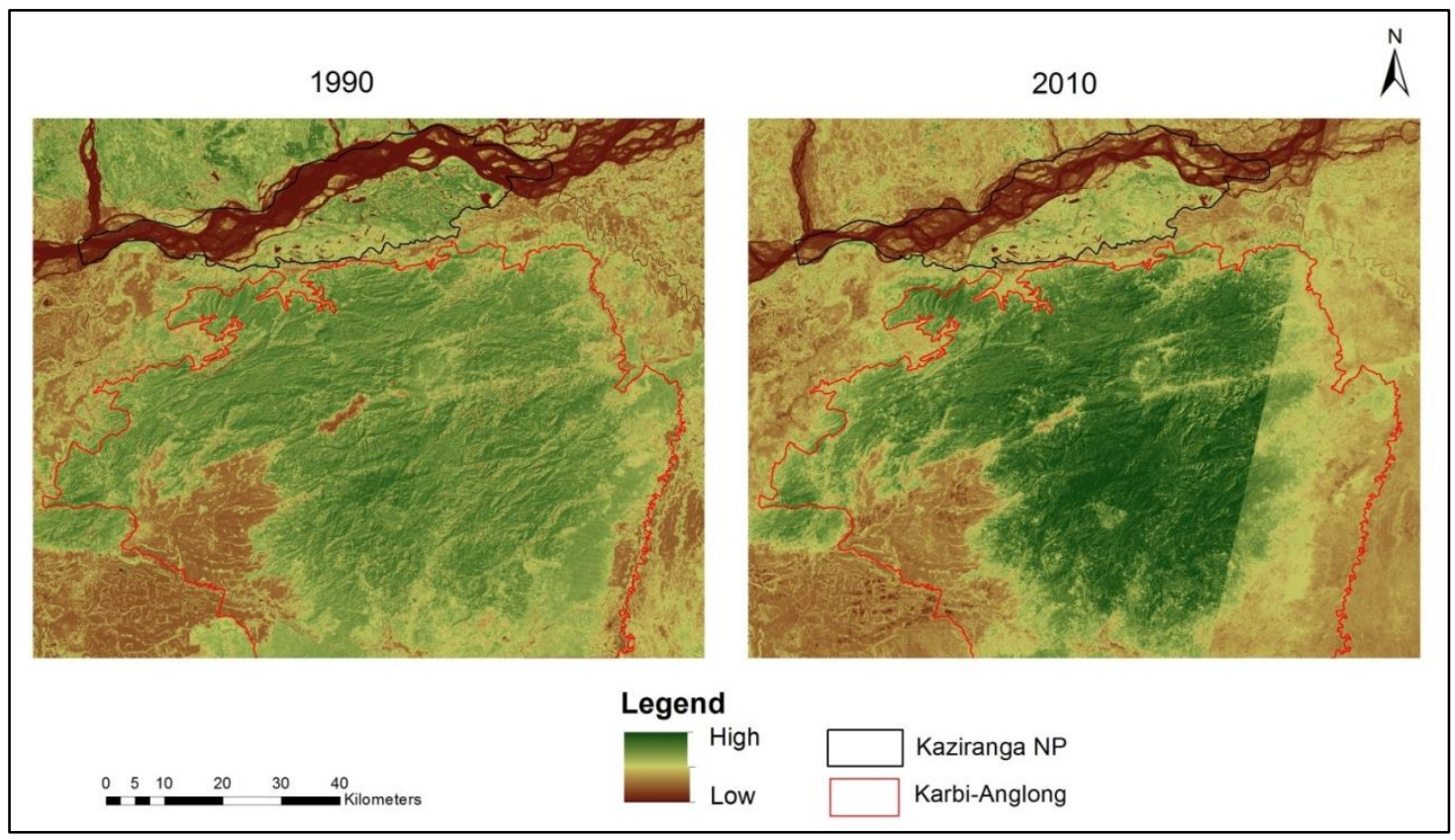




\section{Landscape fragmentation analysis}

The analysis of landscape fragmentation tool reveals that the forests in Kaziranga-Karbi Anglong corridor are fragmented (Fig. 7). There is considerable increase in habitat patchiness, proportion of edge and perforation, indicating that the corridor is shrinking. The analysis also shows the decrease in core areas of forest (Fig. 8).

Fig. 7: Patch, perforation, edge and core in Kaziranga-Karbi Anglong during 1990 and 2010

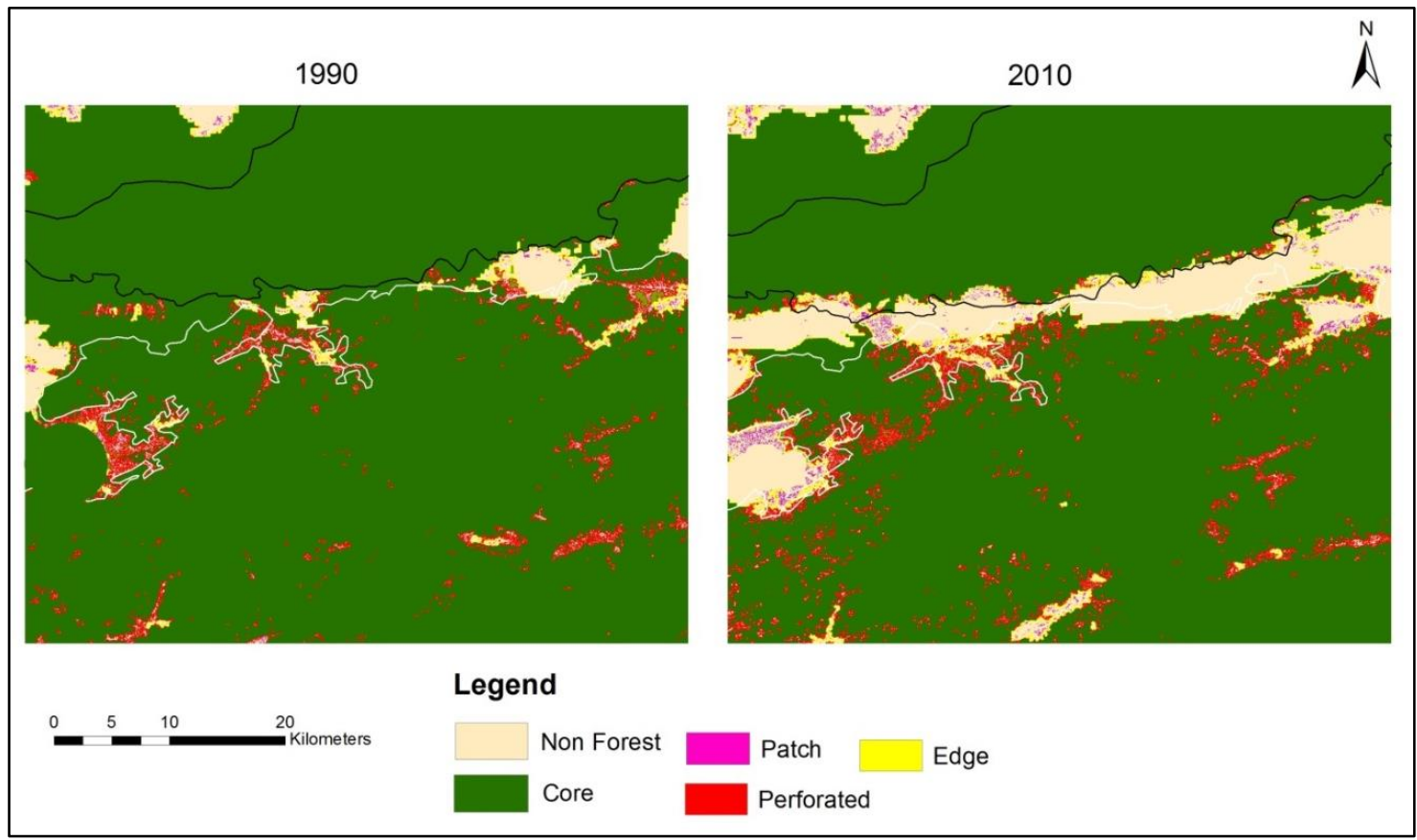

Fig. 8: Proportion of area under landscape fragmentation during 1990 and 2010

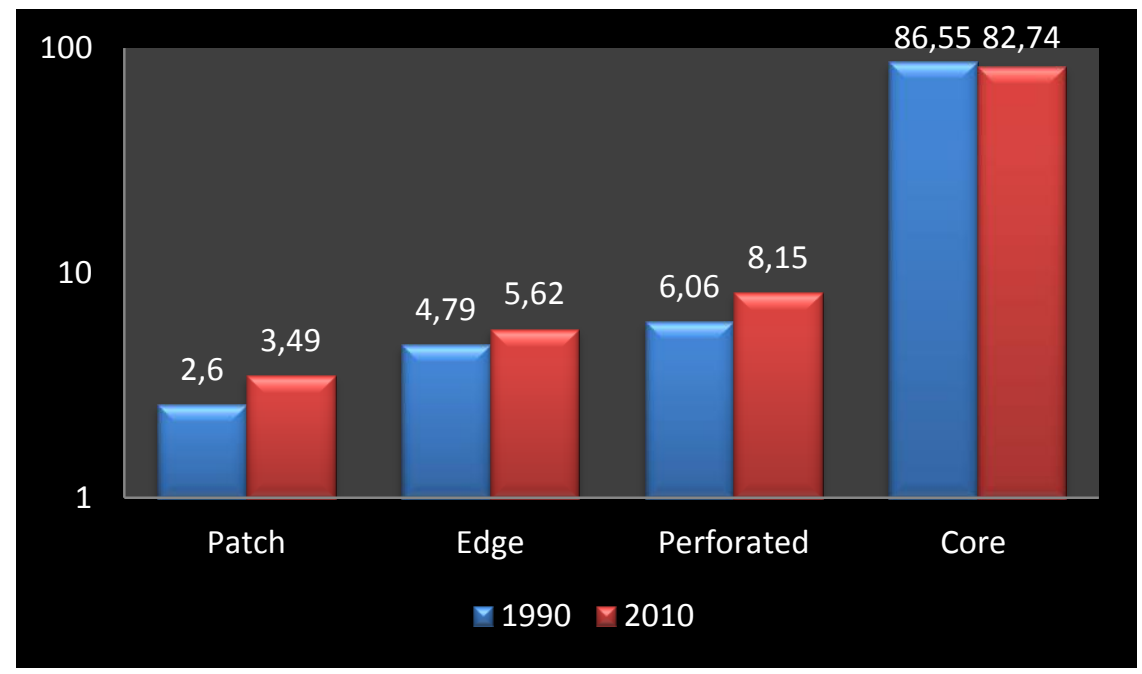


Sharma, B., Sarma, K.: Status Identification and Prediction of Kaziranga-Karbi Anglong Wildlife Corridor of Assam, India, Using Geospatial Technology

\section{Change predictions}

The transition area matrix clearly shows that 2,423,531 pixels from dense forest will remain in the dense forest class, while 967,196 pixels will be converted into open forest; 159,896 pixels will change to scrub forest, and 378,696 pixels from dense forest will change to agricultural land (Table 5). This indicates that the probability of dense forest remaining in the same class is 0.60 by the year 2030 . The probability of conversion of dense forest to open forest or scrub forest is 0.24 and 0.03 , respectively. The probability of change from dense forest to agriculture is 0.094 , whereas the probability of conversion to river, marshy area and open area/river bed is considerably less (Table 6). The probability of changes in forest will increase by 2030 . Some of the non-forest classes also indicate a similar trend. The predicted land use/cover map of Kaziranga-Karbi Anglong corridor (Fig. 9) shows expansion of agricultural land as well as plantation areas, and a reduction in forested land. If the recent probability of conversion persists, only 25.66 and 20.72 percent of the total area will remain under dense forest and open forest in 2030, respectively (Table 7); whereas the area under agriculture and plantation will increase by 33.91 and 5.33 percent, respectively, by 2030 .

Table 5: Transitional area matrix for Kaziranga-Karbi Anglong corridor (Change in pixels)

\begin{tabular}{|c|c|c|c|c|c|c|c|c|c|}
\hline & R & MA & DF & OF & SF & Agr & OA/RB & GL & PLN \\
\hline R & 46443 & 30443 & 3204 & 15939 & 697 & 23317 & 80993 & 30520 & 3433 \\
\hline MA & 37116 & 70723 & 770 & 18699 & 223 & 24838 & 74325 & 67757 & 1770 \\
\hline DF & 12134 & 2453 & 2423531 & 967196 & 159896 & 378696 & 8108 & 4185 & 54224 \\
\hline OF & 19911 & 6736 & 594322 & 1127637 & 135652 & 621417 & 16769 & 7162 & 142142 \\
\hline SF & 665 & 153 & 157883 & 147062 & 46372 & 87633 & 414 & 821 & 16504 \\
\hline Agr & 17089 & 16562 & 119423 & 290847 & 61841 & 2814080 & 31185 & 12460 & 146138 \\
\hline OA & 78383 & 71252 & 1317 & 24625 & 557 & 31703 & 147261 & 67027 & 3196 \\
\hline GL & 5566 & 10975 & 2182 & 4218 & 860 & 4442 & 3286 & 119446 & 187 \\
\hline PLN & 2099 & 163 & 5487 & 25856 & 2317 & 127245 & 302 & 809 & 336970 \\
\hline
\end{tabular}

$\mathrm{R}=$ River, MA=Marshy Area, $\mathrm{DF}=$ Dense forest, $\mathrm{OF}=\mathrm{Open}$ forest, $\mathrm{SF}=\mathrm{Scrub}$ forest, Agr=Agriculture,

$\mathrm{OA}=$ Open Area/river bed, GL=Grassland, PLN=Plantation, TA=Total area

Table 6: Transitional area matrix for Kaziranga-Karbi Anglong corridor

\begin{tabular}{|c|c|c|c|c|c|c|c|c|c|}
\hline & $\mathbf{R}$ & $\mathbf{M A}$ & $\mathbf{D F}$ & $\mathbf{\text { OF}}$ & $\mathbf{S F}$ & AGR & OA/RB & GL & PLN \\
\hline R & 0.1977 & 0.1296 & 0.0136 & 0.0678 & 0.003 & 0.0992 & 0.3447 & 0.1299 & 0.0146 \\
\hline MA & 0.1253 & 0.2388 & 0.0026 & 0.0631 & 0.0008 & 0.0839 & 0.2509 & 0.2287 & 0.006 \\
\hline DF & 0.003 & 0.0006 & 0.6043 & 0.2412 & 0.0399 & 0.0944 & 0.002 & 0.0011 & 0.0135 \\
\hline OF & 0.0075 & 0.0025 & 0.2224 & 0.4221 & 0.0508 & 0.2326 & 0.0063 & 0.0027 & 0.0532 \\
\hline SF & 0.0014 & 0.0003 & 0.3451 & 0.3214 & 0.1014 & 0.1915 & 0.0009 & 0.0018 & 0.036 \\
\hline Agr & 0.0048 & 0.0047 & 0.034 & 0.0829 & 0.0176 & 0.8018 & 0.0089 & 0.0036 & 0.0416 \\
\hline OA & 0.1843 & 0.1675 & 0.0031 & 0.0579 & 0.0013 & 0.0745 & 0.3462 & 0.1576 & 0.0075 \\
\hline GL & 0.0368 & 0.0726 & 0.0144 & 0.0279 & 0.0057 & 0.0294 & 0.0217 & 0.7902 & 0.0012 \\
\hline PLN & 0.0042 & 0.0003 & 0.0109 & 0.0516 & 0.0046 & 0.2538 & 0.0006 & 0.0016 & 0.6723 \\
\hline
\end{tabular}

$\mathrm{R}=$ River, $\mathrm{MA}=$ Marshy Area, $\mathrm{DF}=$ Dense forest, $\mathrm{OF}=\mathrm{Open}$ forest, $\mathrm{SF}=\mathrm{Scrub}$ forest, Agr=Agriculture,

$\mathrm{OA}=$ Open Area/river bed, GL=Grassland, $\mathrm{PLN}=$ Plantation, $\mathrm{TA}=$ Total area 
Fig. 9: Predicted land use/cover for the year 2030

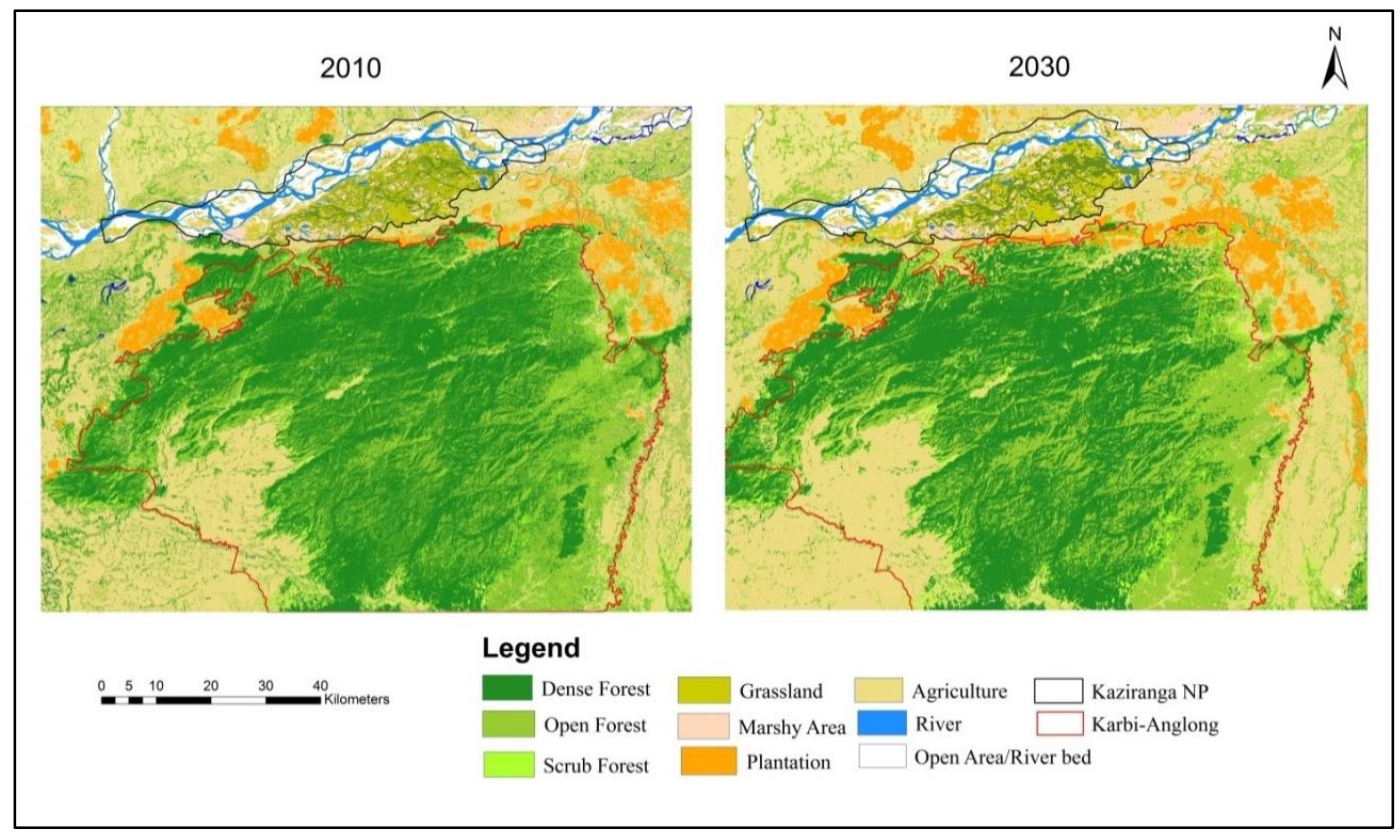

Table 7: Predicted area statistics for Kaziranga-Karbi Anglong corridor for 2030

\begin{tabular}{|c|c|c|}
\hline \multirow{2}{*}{ Land use/cover classes } & \multicolumn{2}{|c|}{ Year 2030 } \\
\cline { 2 - 3 } & Area (sq.km) & \% \\
\hline River & 216.39 & 1.83 \\
\hline Marshy Area & 269.07 & 2.28 \\
\hline Dense Forest & $3,028.23$ & 25.66 \\
\hline Open Forest & $2,445.08$ & 20.72 \\
\hline Scrub Forest & 383.31 & 3.25 \\
\hline Agriculture & $4,002.08$ & 33.91 \\
\hline Open Area/river bed & 339.37 & 2.88 \\
\hline Grassland & 488.24 & 4.14 \\
\hline Plantation & 629.32 & 5.33 \\
\hline Total Area & $\mathbf{1 1 , 7 9 9 . 2 4}$ & $\mathbf{1 0 0}$ \\
\hline
\end{tabular}

\section{DISCUSSION}

The rate of destruction of the wildlife corridor, and the ability to predict the future scenario by applying different algorithms using remote sensing data, has now become of global importance. The fragmentation of forests along the corridor leads to dividing the area into smaller units of a disjointed landscape, and reduces the area of habitat for native animal species. Furthermore, fragmentation isolates species and inhibits movement, reducing the probability of recolonisation in the event that a species disappears from a given patch of habitat (Theobald et al., 1997). Theobald \& Riebsame (1995) and Riebsame et al. (1996) studied the effects of habitat fragmentation on wild animals in the once remote mountainous 
Sharma, B., Sarma, K.: Status Identification and Prediction of Kaziranga-Karbi Anglong Wildlife Corridor of Assam, India, Using Geospatial Technology

western United States; these species were severely affected in various ways, due to various human-related activities in the natural forests. Ehrlén \& Eriksson (2000) and Roy et al., (2010) revealed that many important corridors now start following the managed ecosystems, like crop fields or plantation areas, resulting in the increase of human animal conflicts. Similar studies have been carried out globally (Shirish, 2005; Khanna, 2001; Joshi \& Singh, 2009; Sukumar, 1991; De Silva \& De Silva, 2007; Walpole \& Linkie, 2007; Nelson \& Zubiri, 2003; Hammatt et al., 2004; Bist, 2002; Barua et al., 2010; Gubbi, 2009; Yadav et al., 2012) that support the findings of the present study. Joshi et al. (2011), while predicting the status of land use/cover of Rajaji and Jim Corbett National Parks, using Multi-Layer Perceptron Neural Network (MLPNN), revealed that the areas under anthropogenic influences are tending to increase, while over two consecutive years the wildlife habitat areas were decreasing. The approach of their research bears much resemblance to the present study. Vogt et al. (2007) mapped the landscape corridor of Slovakia, and found about 77 percent of land under core forest was constricted after analysing the forest pattern of different classes. This result seems to be quite comparable with the findings within this study. Their findings concerning the habitat and perforated areas are again identical to the findings of this research.

\section{CONCLUSION}

The Kaziranga-Karbi Anglong corridor is under the influence of vast anthropogenic activities, namely the significant expansion of tea gardens, human habitations and agricultural activities on the southern periphery of the national park. The corridor is threatened by the National Highway 37 which passes through the corridor, and there are regular wildlife road casualty events at this crossing section. Consequently, heavy movement of vehicular traffic and continuous degradation of forested lands have threatened the integrity of the corridor. In recent times, due to the destruction of the natural corridor, the greater one-horn rhinoceros is being killed indiscriminately in and around KNP by poachers; the animals having been forced to deviate from their regular route. The results of the present study should be taken seriously by the authorities, in order to protect the natural forests from further degradation, to meet the broad objectives to conserve and preserve this World Heritage Site.

\section{REFERENCES}

Alfred, J.R.B., Kankane, P.L., Kumar, A., Roy, P.S., Singh, S. \& Verma, M. (2001). Habitat suitability analysis for chinkara, Gazella bennetti in Rajasthan: A remote sensing and GIS approach. Zoological Survey of India Occasional Paper. 189, 1-73.

Areendran, G., Krishna, R. \& Mazumdar, S. (2011). Geospatial modeling to assess elephant habitat suitability and corridors in northern Chhattisgarh, India. Tropical Ecology. 52(3), 275-283.

Barua, M., Tamuly, J. \& Ahmed, R.A. (2010). Mutiny or clear sailing? Examining the role of the Asian elephant as a flagship species. Human Dimensions of Wildlife.15, 145-160.

Bist, S.S. (2002). An overview of elephant conservation in India. The Indian Forester 128, 121-136.

Champion, H.G. \& Seth, S.K. (1968). A Revised Survey of Forest Types of India. Manager of Publications, Govt. of India, New Delhi. 
Conner, R.N. \& Rudolph, D. (1991). Forest habitat loss, fragmentation, and Red-Cockaded Woodpecker populations. Wilson Bull., 103(3), 446-457.

De Silva, M. \& De Silva, P.K. (2007). The Sri Lankan Elephant: Its Evolution, Ecology and Conservation. WHT Publications, Colombo, Sri Lanka.

Ehrlén, J. \& Eriksson, O. (2000). Dispersal limitation and patch occupancy in forest herbs. Ecology. 81, 1667-1674.

Goetz, S.J., Jantz, P. \& Jantz, A.C. (2009). Connectivity of core habitat in the Northeastern United States: Parks and protected areas in a landscape context. Remote Sensing of Environment. 113, 1421-1429.

Gubbi, S. (2009). Elephant deaths due to electrocution: a consequence of inappropriate habitat management? Oryx. 43, 323-324.

Hammatt, H., Fahrimal, D.Y. \& Mikota, S. (2004). Implications of new data for Sumatran elephants in captivity - time for change. In J. Jayewardene (ed.), Biodiversity \& Elephant Conservation Trust: Endangered Elephants: Past, Present and Future (pp. 61-64). Colombo, Sri Lanka.

Hess, G.R. \& Fischer, R.A. (2001). Communicating clearly about conservation corridors. Landscape and Urban Planning. 55, 195-208.

Joshi, P.K., Yadav, K. \& Sinha, V.S.P. (2011). Assessing impact of forest landscape dynamics on migratory corridors: a case study of two protected areas in Himalayan foothills. Biodiversity Conservation. 20(14), 3393-3411.

Joshi, R. \& Singh, R. (2009). Wildlife corridors and Asian Elephants: Lessons from Rajaji National Park, North-West India. Journal of American Science. 5(5), 31-40.

Khanna, V., Ravichandran, M.S. \& Kushwaha, S.P.S. (2001). Corridors Analysis in Rajaji-Corbett Elephant Reserve- A Remote sensing and GIS approach. Journal of the Indian society of Remote sensing. 29 (1\&2), 41-46.

Kushwaha, S.P.S., Roy, P.S., Azeem, A., Boruah, P. \& Lahan, P. (2000). Land area change and rhino habitat suitability analysis in Kaziranga National Park, Assam. Tigerpaper. 27(2), 9-16.

Kushwaha, S.P.S., Khan, A., Habib, B., Quadri, A. \& Singh, A. (2004). Evaluation of sambar and muntjak habitats using geostatistical modeling. Current Science. 86, 1390-1400.

Kushwaha, S.P.S. (2008). West Bengal. Biodiversity Characterization at Landscape Level in Central India and West Bengal using Satellite Remote Sensing and Geographic Information System. IIRS, Dehradun.

Menon, V., Tiwari, S., Easa, P. \& Sukumar, R. (2005). Right of passage, Elephants Corridors of India. Final Technical Report. Wildlife Trust of India.

Michelle, K. \& Nielsen, A. (2008). Modeling potential dispersal corridors for cougars in Midwestern North America using least-cost path methods Cooperative Wildlife Research Laboratory, Southern Illinois University Carbondale, Carbondale, IL, USA. Ecological modeling. 21(2), 372-381.

Mondal, P. \& Southworth, J. (2010). Protection vs. Commercial management: spatial and temporal analysis of land cover changes in the tropical forests of Central India. Forest Ecology and Management. 259(5), 1009 -1017.

Nandy, S., Kushwaha, S.P.S. \& Mukhopadhyay, S. (2007). Monitoring the Chilla-Motichur wildlife corridor using geospatial tools. Journal for Nature Conservation. 15, 237-244. 
Sharma, B., Sarma, K.: Status Identification and Prediction of Kaziranga-Karbi Anglong Wildlife Corridor of Assam, India, Using Geospatial Technology

Nelson, A., Bidwell, P. \& Sillero-Zubiri, C. (2003). A Review of Human Elephant Conflict Management Strategies. People and Wildlife Initiative, Wildlife Conservation Research Unit, Oxford University, United Kingdom.

Phukan, P., Thakuriah, G. \& Saikia, R. (2013). Land use land cover change detection using remote sensing and GIS techniques - A case study of Golaghat district of Assam, India. International Research Journal of Earth Sciences. 1(1), 11-15.

Pontius, R.G. (2000). Quantification error versus location error in comparison of categorical maps. Photogrammetric Engineering \& Remote Sensing. 66(8), 1011-1016.

Rathore, C.S. \& Wright, R. (1993). Monitoring environmental impacts of surface coal mining. International Journal of Remote Sensing. 14, 1021-1042.

Ravan, S.A., Dixit, A.M. \& Mathur, V.B. (2005). Spatial analysis for identification and evaluation of forested corridors between two protected areas in Central India. Current Science. 88(9), 1441-1448.

Riebsame, W.E., Gosnell, H. \& Theobald, D.M. (1996). Land use and cover change in the US Rocky Mountains: I. Theory, scale, and pattern. Mt. Res. Dev. 16 (4), 395-405.

Roy, A., Devi, B., Debnath, B., \& Murthy, M.S.R. (2010). Geospatial Modeling for Identification of Potential Ecological Corridors in Orissa. Journal of Indian Society of Remote Sensing. 38, 387-399.

Sarma, P.K., Talukdar, B.K., Sarma, K. \& Barua, M. (2009). Assessment of habitat change and threats to the greater one-horned rhino (Rhinoceros unicornis) in Pabitora Wildlife Sanctuary, Assam, using multi-temporal satellite data. Pachyderm. 46, 18-24.

Saura, S. \& Torne, J. (2009). Cone for Sensinode 2.2: A software package for quantifying the importance of habitat patches for landscape connectivity. Environmental Modeling \& Software. 24, 135-139.

Shirish, R., Dixit, A.M., \& Mathur, V.B. (2005) Spatial analysis for identification and evaluation of forested corridors between two protected areas in Central India. Current Science. 88(9), 1441-1448.

Sukumar, R. (1991). The management of large mammals in relation to male strategies and conflict with people. Biological Conservation. 55, 93-102.

Theobald, D.M. \& Riebsame, W.E. (1995). Land use change on the Rocky Mountain forest fringe. In Western Conference of the Western Association of Fish and Wildlife Agencies. Big Sky, MT.

Theobald, D.M., Miller, J.R. \& Hobbs, N.T. (1997). Estimating the cumulative effects of development on wildlife habitat. Landscape and Urban Planning. 39, 25-36.

Vogt, P., Kurt, H.R., Iwanowski, M., Estreguil, C., Jacek, K. \& Pierre, S. (2007). Mapping landscape corridors, northern Slovakia (Europe). Ecological Indicators. 7, 481-488.

Walpole, M. \& Linkie, M. (eds.) (2007). Mitigating Human-Elephant Conflict: Case Studies from Africa and Asia. Fauna \& Flora International (FFI), Cambridge, UK.

Yadav, P.K., Kapoor, M. \& Sarma, K. (2012) Land Use Land Cover Mapping, Change Detection and Conflict Analysis of Nagzira-Navegaon Corridor, Central India Using Geospatial Technology. International Journal of Remote Sensing and GIS. 1(2), 90-98.

Zeller, K.A., Nijhawan, S., Pérez, R., Salmo, P., Sandra, H. and Hines, E.J. (2011). Integrating occupancy modeling and interview data for corridor identification: A case study for jaguars in Nicaragua. Biological Conservation. 144, 892-901. 